\title{
AS CONTRIBUIÇÕES DA CANONÍSTICA ÀS INSTITUIÇÕES JURÍDICAS ESTATAIS
}

\section{Carlos Silveira Noronha ${ }^{1}$}

A igreja é uma sociedade fundada na ordem sobrenatural, constituída por uma comunidade universal de seres humanos que a ela se incorporam pelo sacramento do batismo, passando a formar, a partir daí, o chamado povo de Deus. Dotada, no plano humano, de estrutura semelhante à do Estado, embora com este não se identifique, no plano espiritual possui a Igreja o poder de instituir as suas próprias leis para definir o comportamento, os direitos e os deveres da comunidade cristã que a compõe. No inter-relacionamento com outras entidades internacionais, toma a forma estatal e é representada pelo Estado do Vaticano.

Duplo papel exerce a Igreja: o de instituição divina e sobrenatural, como criação do próprio Deus para cumprir os seus desígnios; e como entidade terrena, temporal e profana emergente da própria contingencialidade social e humana do homem no concerto do universo. Embora o aparente antagonismo entre os dois papéis, no exercício da função divina, de ordem sobrenatural, e no desempenho da ação humana, na ordem terrena, na realidade, ambas não se repelem, antes se integram e se completam.

Assim, no seu ofício divino, a Igreja conclama toda a comunidade humana que vive sobre a terra para vir integrar-se à sua grei, pelo ato sacramental do batismo, e a participar da sua vida sobrenatural sob o amparo de uma direção espiritual, voltada para os destinos eternos por Deus reservados ao homem. Na ordem ter-

1 Professor titular de Direito Civil no Curso de Pós-graduação stricto sensu da Faculdade de Direito da UFRGS e no Curso de Direito, da graduação, nas Faculdades Integradas São Judas Tadeu, de Porto Alegre; Mestre e Doutor em Direito pela Universidade de São Paulo (USP). 
rena, projeta-se a Igreja como ente integrante da comunidade universal, dirigida à proteção dos seus fiéis e à convivência com outras entidades.

E para o desempenho desses papéis, que são de natureza complexa, vem a Igreja, desde o estágio inicial da cristandade, editando o seu próprio sistema normativo, fazendo-o por intermédio das Epístolas dos Apóstolos e promulgações de éditos pelas mais altas dignidades da hierarquia eclesiástica², para cumprir a missão de ensinar, santificar e reger os destinos do seu povo, o que na atualidade segue os ditames traçados pelo Concílio Vaticano $\mathrm{II}^{3}$.

Assim, diante da postura assumida pela canonística, especialmente a partir da antiguidade clássica, na convivência mantida com as instituições romanas, há que entender-se as razões em que se fundam os historiadores modernos para afirmar que o direito europeu continental deita suas raízes no sistema romano-canônico ${ }^{4}$.

A projeção desses expedientes históricos manifestados pela via canonística, que vêm sendo arquitetados e edificados pela Igreja para disciplinar seus próprios desígnios, tem trazido, já pela sua anterioridade histórica, notórias contribuições à ordem jurídica estatal, tanto no campo da jurisdição quanto na esfera do direito processual e do direito material.

\section{Das contribuições da canonística no campo da jurisdição e do processo estatais}

No campo da jurisdição, em realidade, as instituições canônicas projetadas no mais remoto andar dos tempos, consubstanciadas em editos das mais altas dignidades da hierarquia eclesiástica, têm trazido significativas contribuições para a concepção moderna da jurisdição estatal. A primeira e multimilenar dessas contribuições reside no relato bíblico, como consta no Evangelho de São Matheus, ao recepcionar a máxima divina, segundo a qual: “Tudo o que ligares na terra, será também ligado no céu e tudo o que desligares na terra será igualmente desligado no céu”, demonstrando aí a delegação do poder divino àquele que desse mesmo poder estiver investido.

2 BICHMANN, Eduárdo. El Derecho Procesal según el Código de Derecho Canónico. Libreria Bosch Barcelona, 1931, p. 1-2.

3 AZNAR, Frederico. Código de Derecho Canónico. Ed. Bilíngue comentada, Cânon,129. Madrid: Ed. BAC, 1985, p. 104.

4 MARRYMANN, John Henry. La Tradición Jurídica Romano-Canónica. Trad. esp. de Carlos Sierra. México: Fundo de Cultura, 1971, p. 29. 
Desse modo, há que se admitir que o poder judicial da Igreja foi imediatamente exercido pelos Apóstolos, na qualidade de representantes de Cristo, o que significa, consequentemente, entender-se que nesta proclamação divina reside o primeiro laivo ou gérmen exemplificativo de que também na jurisdição estatal ao juiz é atribuído o poder jurisdicional de atuar como representante do poder do Estado.

Mas é no campo do processo que a canonística vem se projetando mais sistemática e continuadamente, desde os primeiros tempos da cristandade, como se verá a seguir. A princípio, o poder judicial da Igreja, como se viu, foi imediatamente exercido pelos Apóstolos, no Século I d.C., e estes, devido ao diminuto número de fiéis na época e à perseguição dos Imperadores romanos, reuniam-se escondidos nas catacumbas, na qualidade de Discípulos diretos de Cristo, sendo posteriormente substituídos pelos bispos. O primeiro órgão judiciário, na esfera canônica, foi a episcopalis audientia, ou tribunal do bispo, o foro judiciário de que se valiam as autoridades eclesiásticas para julgar as causas dos fiéis, exercendo- -as publicamente só a partir da legislação de Constantino (306-337) ${ }^{5}$.

Posteriormente, o tribunal episcopal experimentou algumas restrições impostas pela legislação imperial, sendo proscrito entre 361 e 363 por Juliano, o apóstata, e restaurado por Joviano em 364. Continuou a enfrentar restrições até uma constituição de 17 de maio de 376, dos imperadores Valente Graciano e Valentiniano. Pelas Novelas 79 e 86 de Justiniano (527-565), do ano 539 d.C., e pela Novela 123 do mesmo imperador, no ano 541, foi a jurisdição episcopal sobremodo ampliada, repristinando-se, inclusive, a proibição de submeter os bispos à jurisdição civil, precedente que vinha desde a constituição de 355, de Constancio é Constante (Cód. Th. 16, 2, 12) $)^{6}$.

Com a decadência do Império Romano do Ocidente em 476 d.C., no episódio da vitória de Odoacro, rei Godo, sobre Romulo Augustolo, então rei Romano, e a consequente invasão dos bárbaros, a Igreja, por sua aversão à crueldade dos juízos de Deus, peculiares ao antigo processo dos germânicos, enfrentou muitas dificuldades. Essas perduraram por mais de três séculos, enquanto os dominadores se manti-

5 ARIAS, José V. Salazar. Dogmas y Cânones de La Iglesia em El Derecho Romano. Madri: Instituto Editorial Réus, 1954, p. 299-304.

6 ARIAS, José V. Salazar, ob. cit., p. 328-329. 
nham hostis aos princípios e dogmas do cristianismo romano.

Mas, ao ano 800 da era cristã, o Papa Leão III coroou imperador a Carlos Magno, rei dos Francos, ocorrendo, assim, a translatio imperii, antes sob o poder de Bizâncio, consumando-se nesse ato a renovatio imperii, que daria origem ao que algum tempo depois chamou-se "Sacro Império”. Restabeleceu-se o poder eclesial perante a autoridade profana, diga-se romana, e já no ano seguinte, em 801, o rei Franco julgava uma causa em favor do bispo de Siena ${ }^{7}$.

Notadamente durante todo o período imperial romano, verificou-se uma duplicidade de jurisdições entre a Igreja e o Império, ambas independentes e exercidas com poder que provinha de Deus, às vezes compartilhada entre o poder divino e o poder estatal. De um lado, a auctoritas sacrata pontificium, que emanava do poder papal, com a função de cuidar das coisas espirituais; de outro, a regalis potestas, emergente do poder real, para cuidar das coisas materiais. Assim, no plano espiritual, o Imperador subordinava-se ao Papa, enquanto que no terreno das coisas temporais, devia o Papa obediência ao Rei ${ }^{8}$.
Embora não se possa ignorar as dificuldades iniciais do direito da Igreja na época do Principado, não foram poucas as oportunidades em que o direito e os tribunais canônicos foram estendidos aos leigos. $\mathrm{E}$ isso se deveu não só à natureza de direito público, transcendente ao interesse individual, reconhecida ao direito canônico, mas também em razão de revelar-se a atuação da Igreja de caráter transcultural e transnacional, de modo que a eficácia de suas leis, cânones e procedimentos devia estender-se a todos os povos do universo. Desse modo - como observa recente doutrina canônica - do complexo de misteres eclesiais, sobressaia-se o aspecto Ecclesia iuris, que colimava a união de todos os homens pela graça divina, conforme atualmente proclama o Concílio Vaticano II. ${ }^{9}$

Ainda um outro resultado da militância ultramilenar conjunta entre o ius romanum e o ius canonicum é a existência no direito moderno de uma plêiade de institutos que têm origem no direito canônico, tais como: os da citação; da conciliação; da assistência judiciária gratuita; da querella militatis; da instituição do processo sumário pelas Clementinae Saepens

7 SILVA, Nuno Espinosa Gomes da. Ob. cit., p. 130. Sobre as relações da Igreja com o Imperador Carlos Magno, ver Salvioli, Ob. cit ., p. 49-50 e 56-57.

8 SILVA, Nuno Espinosa Gomes da. Ob. cit ., p. 120-131.

9 ANTA, Marcelino Cabreros de. Iglesia y Derecho, Hoy. Pamplona: Ed. Universidad de Navarra, 1975, p. 93-104. 
de 1306, do Papa Clemente V (13051314); e muitos outros que hoje são adotados pelo processo dos nossos dias. O próprio instituto da jurisdição teria sua remota origem no evangelho de São Matheus, como mencionado anteriormente.

Acresça-se a esses fatores a posição da doutrina canônica espe-cializada que considera a norma canônica vocacionada a uma função instrumental, não como fim em si mesma, mas como meio e um dos meios de que se vale a Igreja para chegar aos seus fins ${ }^{10}$.

Nessa perspectiva, não é de estranhar-se a interação que no transcurso dos tempos vem se verificando entre o Direito Romano e o sistema canônico na prática dos tribunais leigos e na dos tribunais eclesiásticos. Essa conjugação de caminhos e objetivos contribuiu para fornecer os fundamentos do direito comum ou utrumque ius, fruto dos estudos de Bolonha que ensejaram o renascimento do Direito Romano justiniâneo e para os quais contaram os glosadores com a contribuição estreita dos canonistas no sentido de promover, ao lado da reforma do ius civile, a renovação do lus canonicum. Assim, os princípios comuns do Direito Romano e do Direito Canônico, modelados também pelos influxos do antigo Direito Germânico, vão produzir, pela exegese dos glosadores e interpretação dos comentadores, um processo misto ou comum a ser aplicado genericamente sempre que não se tornar-se incompatível com as leis locais e que se chamou, também, processo romano-canónico.

Esse processo misto, como ius novum, resultante de uma comistão do direito justiniâneo com o direito da Igreja, foi, em momento ulterior, admitido pela maioria dos ordenamentos europeus, estendendo-se ainda à América Latina em razão dos descobrimentos de ultramar desenvolvidos por espanhóis e portugueses.

\section{Da postura canonista em época pré-graciânica}

Costuma-se denominar época pré-graciânica, na história do Direito Canônico, o período ultramilenar que transcorreu entre o início da era cristã e o Decreto de Graciano (em 1140), quando a Igreja Católica, com base nas catacumbas de Roma e por meio de Concílios, Encíclicas papais e compilações privadas, completa o período de formação do seu Direito, pois as fontes mais remotas da ciência canônica retroagem às Sagradas Escrituras, compostas do Velho e do Novo Testamento. As primeiras continham preceitos cerimoniais sobre o culto, preceitos judiciais sobre a vida do povo de Isra- 
el como sociedade e preceitos morais que foram confirmados por Cristo. As segundas contêm os preceitos firmados por Cristo legislador, classificados em preceitos de direito divino, referentes ao Evangelho, preceitos de direito divino-apostólico, pertinentes à organização clerical, e preceitos de direito apostólico emanados das práticas evangélicas realizadas pelos Apóstolos, em contato com o Clero.

Como registram os historiadores canônicos, em sua fase inicial, a chamada Igreja primitiva, entre os Séculos I e III, preocupava-se mais propriamente com a cultura da alma, passando a dedicar-se à parte profana ou laica só a partir dos séculos seguintes ${ }^{11}$.

Segundo Salazar Arias, porém, a legislação canônica, contando inclusive com normas processuais relativas a episcopalis audientia, teria iniciado já no primeiro século, quando o Papa Cleto (76-88) proibiu os cristãos de procurar os tribunais leigos, devendo dirigir-se aos tribunais eclesiásticos de sua própria província. As regras processuais necessárias à disciplina dos tribunais episcopais teriam sido pouco a pouco editadas pelos Romanos Pontífices, em complemento à legislação divino-apostólica já exis- tente, permitindo assim um desenvolvimento uniforme dos ditos tribunais.

Provavelmente, as dificuldades em identificar esse tribunal eclesiástico nos primeiros tempos tenha ocorrido devido ao fato de que o vocábulo " $a u$ dientia" não se incluía na denominação do tribunal, que se chamava judicis cognitio publica. Era, pois, a palavra audientia substituída por judicium.

Assim, quando Constantino expediu o édito de Milão, no ano 313 d.C. convertendo-se ao cristianismo e dando à Igreja a paz de que não havia anteriormente gozado, a episcopalis audientia se desenvolvia até então ocultamente, como tribunal exclusivamente da Igreja. Quando pela constituição do ano de 318 o mesmo Imperador transformou o tribunal eclesiástico em instituição pública e o reconheceu não só pelo Direito Canônico como também pelo Direito Romano $^{12}$, operou-se profunda transformação na jurisprudência eclesiástica. Assim, três consequências importantes ocorreram: primeira, era esta estendida às causas civis, sempre que o interessado optasse pelo tribunal do bispo, ainda que o pedido fosse só de uma das partes; segunda, restava excluída a jurisdição estatal para as causas eclesiásticas, ainda que a parte a

11 GARCIA, Antonio Garcia y. História Del Derecho Canônico - El Primer Milênio, Selemanca, 1967, p. 33-43.

12 ARIAS, José V. Salazar. Dogmas y Cânones de La Iglesia em El Derecho Romano. Madri: Instituto Editorial Réus, 1954, p. 121-124, 299-306, 128-129, 35-318, 130, 321-322. 
postulasse; terceira, a decisão eclesiástica tornou-se inapelável ${ }^{13}$.

Justiniano, que reinou de 525 a 565 d.C., legislou copiosamente sobre a jurisdição eclesiástica por constituições contidas principalmente no Código e nas Novelas, estabelecendo um perfeito equilíbrio entre a jurisdição canônica e a imperial romana e sustentando o princípio de colaboração entre as duas potestades, que já vinha desde a época de Constantino. Tudo isso se operava pelos fenômenos da recepção, pelo direito imperial, das leis e disciplinas praticadas pela Igreja às relações com seus fiéis, bem como a recepção, pelo direito canônico, das normas processuais romanas quanto à competência e funcionamento dos tribunais eclesiásticos e notadamente o tribunal do bispo ou episcopalis audientia. Assim, não se pode deixar de estabelecer certa analogia entre o sistema justiniâneo e aquele que mais tarde, já quase ao final da Alta Idade Média, por obra de glosadores e pós-glosadores, iria ensejar o surgimento do processo comum ou romano-canônico ${ }^{14}$.

Com a decadência do Império Romano do Ocidente, em 476 d.C., e as invasões do território itálico pelos povos de raças germânicas, a atuação da Igreja, no campo das atividades públicas, sofria as mesmas consequências negativas de que fora alvo nas instituições imperiais romanas. A primeira restrição foi a de limitar a atuação dos tribunais eclesiásticos ao julgamento exclusivo das causas religiosas, criando-se problemas com o sistema probatório dos dominadores, porquanto era a igreja fundamentalmente contrária aos chamados juízos de Deus que infligiam torturas à parte a quem competia provar que tinha razão na disputa litigiosa.

A situação tornou-se um pouco melhor em fins do Século VIII e início do Século IX com as capitulares carolíngeas, no império longobardo-franco, quando o imperador Carlos Magno fez aliança com o Pontífice Romano, Leão III.

\section{Do Decreto de Graciano}

Graciano, cujo nome completo era Graciano de S. Félix e Nabor, foi um monge Camaldulense, professor de teologia em Bolonha que organizou no ano de 1140 uma Concórdia Discordantium Canonum à qual foi logo dado o nome de Decretum. Consta haver sido o autor auxiliado por Rolando Bandinelli, que em 1159 se tornaria o Papa Alexandre III. Reunia o Decretum Graciani cerca de 3.800 textos ordenados

13 ARIAS, José V. Salazar. Dogmas y Cânones de La Iglesia em El Derecho Romano. Madri: Instituto Editorial Réus, 1954, p. 323-325.

14 ARIAS, José V. Salazar. Dogmas y Cânones de La Iglesia em El Derecho Romano. Madri: Instituto Editorial Réus, 1954, p. 133-149, 328-355. 
sistematicamente, seguindo o método e pensamento de seu antecessor Ivo de Chartes. Havia a separação do Direito Romano, do Canônico, destacando-se este da teologia, que antes eram estudados juntos. Era uma compilação particular, na qual estavam reunidas Bulas, cartas, epístolas e outras publicações papais para serem seguidas pelos tribunais eclesiásticos.

Segundo alguns canonistas, a obra de Glauciano serviu como marco divisor do sistema canônico em dois períodos distintos, o do "ius vetus", até Graciano, e do “ius novum”, após Graciano, incluindo-se neste último as Ordenações de Gregório IX, de 1234, a nova compilação Sacrossanta Ecclesia, de Bonifácio VIII, de 1298, e as duas codificações oficiais do Código Canônico de 1917 e o atual de 1983.

A metodologia do Decretum era inovadora, dispondo-se as matérias ordenadamente, o que não ocorria nas compilações anteriores. A obra não era apenas uma coleta de textos, mas para cada conjunto de documentos sobre uma determinada questão o autor emitia um dictum ou comentário breve, resumindo o problema e propondo a solução. O conjunto desses peque- nos comentários foram chamados os dicta Gracíani, havendo contribuído para dar maior clareza à obra, que se tornou de grande utilidade para os estudos de direito canônico nas Universidades $^{15}$. Formava a obra verdadeiro liame que ligava o passado e o presente da canonística.

Na sua condensação de textos e compilações, o Decretum apresentava duplo aspecto, pois se de um lado fazia uma reprodução dos princípios que na época de Graciano governavam o processo, de outro constituía-se no documento que reunia até aquele momento histórico todos os elementos constitutivos dos princípios admitidos no ultramilenar espaço de tempo anterior a Graciano e que serviriam de base à renovação das instituições canônicas que em futuro breve se iniciaria.

Era o Decreto dividido em três partes: a primeira referia-se às fontes e às pessoas; a segunda cuidava das causas judiciais; e a terceira da liturgia (De consecratione $)^{16}$.

A compilação graciânica ocupava-se, relativamente ao processo, das três fases distintas da função de conhecimento, da fase recursal e da estrutura humana necessária para o funcionamento do juízo: iudex, advo-

15 GILISSEN, John. Introdução Histórica ao Direito. Lisboa: Fundação Calouste Gulbenkian, 1986, p. 147-148.

WICAKER, Franz. História do Direito Privado Moderno. Lisboa: Ed. Fundação Gulbenkian, 1967, p. 71-72.

16 Preleção do professor José Rogério Cruz e Tucci no curso de Pós-Graduação da Faculdade de Direito do Largo de São Francisco (USP), em 29 set. 1989. 
gado, procurador e auxiliares, dentre esses, o encarregado da citação e da atestação da revelia do demandado, fazendo ainda as distinções entre verus iudex, pelos critérios jurídicos (imparcialidade), e bonus iudex, por critérios morais (garantias morais de seriedade e independência), respectivamente, como requisitos de que deveria estar exornada a pessoa do juiz para obter-se uma boa judicatura.

Podia-se considerar a Concórdia Discordantium Canonum como um pródromo prenunciador de uma evolução específica que Graciano estava anunciando no campo dos princípios do direito processual da Igreja, pois antes dele só se encontravam nas coleções canônicas normas de direito romano e de direito germânico trasladadas para o ordenamento eclesial.

As três fases do processo cognitivo a que se referia o Decreto eram, como se viu: a introdução, a instrução e a definição. Na introdução, estavam contempladas o libelo, a citação, a contestação da lide e, após esta, o ato formal da litis contestatio, que não diferia, quanto ao conteúdo e efeitos, do mesmo ato praticado perante o direito romano justiniâneo, isto é, servia apenas para constatar-se a pretensão do autor invocada no libelo, a contrariedade do réu, ou a sua aquiescência ao pedido do autor (confessio in iure), ou, ainda, a revelia do demandado. Servia, assim, a litis contestatio tão só para fixar os limites do litígio, não refletindo nenhuma influência na sentença. Na instrução, eram considerados os vários meios de prova, especialmente as provas orais do juramento e da testemunhal, às quais era conferida elevada valoração, em vista dos conteúdos de direito divino que as informavam, de modo a produzir no exame das mesmas as medidas de moralidade e de pecado que estas poderiam conter. No que pertine ao juramento, partia Graciano do princípio de que jurare non est pecatum.

Finalmente, na parte relativa à definição do processo, situava-se a sentença. Acerca desse fundamental ato do processo, pouco se refere o $D e$ cretum, limitando-se a traçar algumas regras, demonstrando preocupação com os conteúdos morais que deviam estar presentes na sentença, como documento destinado a refletir a verdade processual, bem como uma perfectível vontade substancial.

Para que se obtivessem tais resultados, Graciano ditava alguns requisitos de ordem processual a serem observados na sentença. Em primeiro lugar, fixou um dos princípios cardiais do processo eclesiástico, que era a pluralidade de graus de jurisdição para firmar outro princípio fundamental consubstanciado na tríplice sentença conforme, isto é, a exigência de três julgamentos no mesmo sentido para alcançar-se a autoridade da coisa julgada sententia quae in se non valet confirmata per superiorem valet (c. 
6.C.35.q.9); sententia definitiva obtinet auctoritatem rei judicatae (c.29.C.2 q. 6); sententia non tenet quando per appellationem intra certum tempus relevatur (c. 2. C. 35. p. 9).

Por outro lado, Graciano estabelecia certos requisitos de ordem espiritual e moral para a sentença, que se encontravam particularmente vivo no contexto da canonística, tais como: iudex debet eam ferre cum mentis tranquillitate non in furore, significando que o juiz devia estar mentalmente tranquilo, não se deixando levar pela ira ao prolatar a sentença iniusta (sententia) nocet potius ferendi quam patientí, significando a máxima de que a sentença injusta prejudica mais o agente do que o paciente; iniqua sententia est revocanda, isto é, a sentença iníqua deve ser revogada.

Por fim, Graciano ditava algumas regras de ordem substancial a serem observadas pelo Juiz: non secundum propriam voluntatem sed secundam leges (senteniia) est proferenda, querendo dizer, em vernáculo, que a sentença deve ser proferida não segundo a vontade do juiz, mas de acordo com a lei, non est danda sententia nisi post, plenam investigationem veritatis, significando a máxima de que a sentença injusta prejudica mais o agente do que o paciente; iníqua sententia est revocanda, isto é, a sentença iníqua deve ser revogada.

Nessas recomendações de Graciano dirigida ao juiz sobreleva o concei- to de justiça da sentença, que devia se ancorar no animus e na tranquillitas mentis, ou seja, nos conteúdos moralista-espiritualistas que constituem os pontos de gravitação em que se ampara a ciência canônica.

Diante dos princípios de moralidade e de espiritualidade que se constituem em pontos cardiais para o direito da Igreja, como se viu acima, é de se concluir que, embora não estivesse expresso, como nas codificações modernas (Código de 1917, cânon 1.869, Código de 1983, cânon 1.608), Graciano admitia na sua compilação o requisito da certeza moral na elaboração da sentença.

Quanto aos outros requisitos formais, a sentença devia ser prolatada pelo juiz, normalmente o bispo, no seu tribunal, a episcopalis audientia, e, segundo expressamente dispunha o Decretum, por escrito, sententia debet dari in scriptis (c.7.C.2.q.1). Desse modo, a episcopalis audientia foi definitivamente renovada por Graciano.

Os atos do juiz eram o decretum, com o qual era o processo ordenado e desenvolvido, e as sententiae, que se dividiam em sententiae definitivae e sententiae interlocutoriae.

As primeiras eram impugnáveis pela appellatio, tanto as injustas ou iníquas quanto as nulas, pois, segundo a doutrina posterior de Liebman, por longo tempo, tanto no direito romano quanto no direito medieval, as sentenças, inquinadas de errores in indican- 
do e as com errores in procedendo, eram passíveis do recurso de apelação ${ }^{17}$, completando-se a assertiva com Della Rocca, para quem a querella nullitatis, para atacar a sentença nula, só teria surgido da confluência da $e x-$ ceptio nullitatis das Decretais com a actio nullitatis do processo comum ${ }^{18}$.

A sentença interlocutória era apelável no Decretum Graciani por disposição expressa (c. 38. q. 6. C. II), que a identificava com a sentença definiti$v^{19}{ }^{19}$ Aliás, tal posição assumida na dita compilação não era de se estranhar, porque essa era a regra no processo canônico, desde que, em contato com o processo germânico antigo, teve o seu procedimento dividido em fases estanques - termini ou stadia - encerrando-se cada terminus com provimento judicial, que no processo romano chamava-se interlocutio e no processo canônico passou a denominar-se sententia interlocutoria. A apelação para a sentença definitiva e para a interlocutória devia ser formulada no prazo de dez (10) dias, dirigida ao órgão judicial imediatamente superior ao que a havia proferido inicialmente, salvo o recurso para a Sé Apostólica (Rota Romana e Supremo Tribunal da Assinatura Apostólica) ou diretamente ao Romano Pontífice, podendo o recurso ser, nesse caso, per saltum.

Contra as sentenças definitivas válidas e transitadas em julgado, cabia o recurso extraordinário da restitutio in integrum.

Para o trânsito em julgado, exigia-se uma tríplice sentença conforme, pois quanto a esse requisito a situação da época pré-graciânica se mantinha inalterada, de vez que a tríplice conforme só se teria alterado para dupla conforme em 1917, com a primeira codificação canônica oficial ${ }^{20}$.

Em conclusão do tema objeto dessas passagens do Decretum, há que se referir a transcendental importância da obra de Graciano para o direito da Igreja Católica Romana, pois há autores, como Della Rocca, que a con-

17 LIEBMAN. Appunti Salle Impugnazioni, p. 1, 3 XIII ristampa, Ed. CisalpinoGolliardica, Milão, 1961.

18 ROCCA, Fernando Della. Instituciones de Derecho Procesal Canônico. Trad. Esp., Buenos Aires: Ed. Desclée de Brouwer, s/d., p. 348-349. “Appunti sui Gravami nel Processo Canônico", in Saggi di Diritto Processuale Canônico, p. 173. Padova: CEDAM, 1961.

19 Sobre essa disposição do Decreto de Graciano, ver PELLEGRINO, Piero. II Prowedimenti Interlocutori nella Teoria Canonistica delle Impugnazioni. Padova: CEDAM, 1969, p. 17.

20 Sobre a tríplice sentença conforme, ver HERNANDEZ, Miguel Moreno. Derecho Procesal Canonico. Madrid: Ed. Aguilar, 1956, p. 334-336. 
sideram "latto di nascita del diritto canônico; ciò che storicamente è inconfundibile"; enquanto outros, como Wieaker, consideram o Decretum o marco indelével entre duas épocas da ciência canônica ${ }^{21}$.

\section{Das Decretais de Gregório IX}

No ano de 1230, o Sumo Pontífice Gregório IX, sucessor de Honório (1216-1227) e sobrinho de Inocência III (1198-1216), devido ao grande número de decretais promulgadas após o Decreto de Graciano, de 1140, resolveu publicar uma consolidação autêntica e exclusiva, em que reuniu as respostas pontificais a consultas formuladas por bispos e doutores da cristandade, na época denominadas Litterae, Epistolae, decretales, epistolae tractatoriae, conferindo a essa compilação a denominação de DECRETAIS.

Para realizar a obra, foi encarregado o confessor de Gregório IX e velho Professor de Lógica em Bolonha, o dominicano espanhol Raimundo Peñafort. Realizado o trabalho, foi a compilação promulgada por Gregório IX pela Bula Rex Pacificus, de 5 de setembro de 1234 .
A obra compilada por Raimundo Peñafort, que depois foi canonizado Santo da Igreja, dividiu-se em cinco livros, nos quais a matéria foi distribuída na mesma forma como haviam sido as cinco compilações antigas, na seguinte ordem: o Livro I tratava do iudex; o Livro II, do iudicium; o Livro III, do clerus; o Livro IV, dos connubia; e o V, dos crimina. Cada livro foi dividido em títulos, e cada título em Capítulos ou cânones, cada um dos quais reportando-se no todo ou em parte ao texto da decretal de que se ocupava $^{22}$.

Promulgadas as Decretais em 1234, foram declaradas universais e exclusivas, revogando todas as compilações anteriores, com exceção do Decreto de Graciano. As Decretais foram também conhecidas por Líber Extra e tiveram grande aceitação. Não se limitavam a cuidar apenas dos assuntos do clero, mas influíram nas legislações laicas que surgiram no futuro, pois os governantes usavam as Decretais como parâmetro para a elaboração de suas codificações, devido à unidade, à garantia e à segurança que revelavam em sua estrutura, quando também passaram a adotar a

21 Acerca das instituições processuais canônicas contidas no Decretum de Graciano, ver por todos, extensivamente, ROCCA, Fernando Della. II Processo in Graziano, "passim”, in Saggidi Diritto Processuale Canônico. Padova: CEDAM, 1961, p. 203226. WIEAKER, Franz. História de Direito Privado Moderno. Lisboa: Fundação Gulbenkian, 1967, p. 361.

22 CIPROTTI, Pio. Lezioni di Diritto Canônico. Padova: CEDAM, 1943, p. 97-99. 
sistemática das Decretais, dividindo-as em cinco Livros, como ocorre até hoje, tornando-se, assim, de grande valia para a formação do direito medieval e também do moderno. Autores há que as consideram "a pedra angular do edifício canônico até o Código”23.

A matéria pertinente ao processo encontrava-se no Livro II, dividida em 30 títulos e 421 Capítulos, sendo o mais extenso o Título XXVIII, que era dividido em 73 capítulos, intitulado De appellationibus, recusationilus et relationibus, enquanto o Título XXVII, composto por 26 capítulos, tratava da sententia e da res iudicata.

Para iniciar-se o processo, o autor comparecia perante o juiz e apresentava-lhe uma postulatio, ordenando-se a citação a, in ius vocatio do réu para comparecer perante o juiz, ocasião em que o autor apresentava petição da demanda, a libelli oblatio, dando-se ao demandado um prazo para oferecer todas as exceptiones, dilatórias, peremptórias e provas (contestação) que, por prescrição de Inocêncio III, deviam ser oferecidas de uma só vez, in eventum.

Com o libelo do autor e a exceptio do réu, chegava-se a litis contestatio, por meio da qual formalizava-se o objeto do litígio, a res in indicium deducta, ficando vedadas daí por diante alterações unilaterais no processo.
Note-se que a litis contestatio era apenas $\mathrm{o}$ ato formal de encontro das partes para firmar o juízo. Nela não se registrava nenhuma convenção entre ambas, como no processo romano clássico, pois o dito ato, nesse passo, gerava a mesma eficácia da que se realizava no processo romano justiniâneo, salvo se o réu quisesse realizar a confessio in iure, mas isso não era o que curialmente acontecia. Desse modo, a litis contestatio não influía na sentença, salvo nos sistemas canonísticos e romano anteriores, nos quais a litis contestatio constituía novação da lide.

Abre-se a fase probatória, necessitando serem provados somente os fatos controversos, mediante os articuli probationis. Havia tarifamento da prova: probatio plena e probatio semiplena.

Encerrando-se a fase probatória com a conclusio in causae feita a publicatio do resultado da prova, o juiz proferia a sentença, condenando ou absolvendo o réu e comunicando às partes para do ato tomarem conhecimento terminus ad sententiam audiendam. A sentença iniciava-se com a invocação in nomine Dei, e antes de ser uma sentença condenatória e executiva, devia ser uma sentença justa, mediante a certeza moral do juiz, características que a distinguiam da sentença civil atual.

23 GIGANTE, José Antonio Martins. Instituições de Direito Canônico. V. I, n. 23, Braga: Ed. Escola Tip. da oficina São José, 1951, p. 27-29. 
Quanto aos demais requisitos da sentença, cabe salientar que há dúvidas a respeito da motivação. O professor José Rogério Tucci entende que não havia obrigatoriedade da fundamentação da sentença ${ }^{24}$. Há, no entanto, autores que optam pela motivação, no âmbito do processo romano-canônico ${ }^{25}$. Não resta dúvidas de que, ainda na falta de norma legal que o obrigasse, não estava o juiz impedido de motivá-la, pois tal faculdade pode-se entender incluída na iurisdictio e no ius imperii do prolator da sentença.

A esse propósito, é de lembrar-se aqui um registro de Pertile, de que desde os tempos antigos os juízes eclesiásticos "estavam acostumados a dar os motivos das suas próprias sentenças”, o mesmo acontecendo com os tribunais civis em tempos de Século XII. Esse costume era de tal modo observado que muitos não concebiam uma sentença que não fosse motivada. Mas, de outro lado, havia jurisconsultos que não consideravam essencial essa solenidade no direito comum, como Tan- credus, enquanto outros, como Durante, taxavam-na de perigosa ${ }^{26}$.

A sentença devia ser escrita, pois todos os atos do processo obedeciam ao princípio da escritura, ou se realizados oralmente, deviam reduzir-se a escrito para se perpetuarem nos autos (quod non est in actis, non est in mundo), por exigência da Bula Quoniam Contra, do ano de 1210, de Inocêncio III, anterior, portanto, às Decretais gregorianas.

A sentença nula por errores in procedendo devia, por conclusão lógica, passar a ser atacada, a partir das Decretais, pela quarella nullitatis em vez da apelação, como vinha acontecendo desde o sistema romano. Segundo doutrina assente entre processualistas civis e canonistas, esse novo recurso extraordinário, que se projeta no mundo processual como recurso típico do processo canônico, teria surgido da confluência da exceptio nullitatis das Decretais com a actio nullitatis regida pelo processo comum ${ }^{27}$. No entanto, há uma corrente de ca-

24 TUCCI, José Rogério Cruz e. A motivação da sentença no processo civil. São Paulo: Saraiva, p. 37-47, 1987.

25 Entendem que a sentença do processo romano-canônico era motivada. ABADIA, Jesus Lalinde. Derecho Histórico Español. Barcelona: Ed. Ariel, 1974, p. 566. GUASP, Jaime. Derecho Procesal Civil. Tomo I. Madrid: Ed. Institutos de Estúdios Políticos, p. 75, 1968.

26 PERTILE, Antonio. Storia Del Diritto Italiano. V. VI, "Storia della Procedura”, § 239. Turim: Unione Tipográfico-Editrice Torinese, 1900 p. 223-224.

27 HEERNANDEZ, Miguel Moreno. Ob. Cit ., p. 317. ROCCA, Fernando Della. Instituciones de Derecho... Trad. Esp., cit., n. 167, p. 348. LIEBMAN. Appunti Sulle Impugnazioni, cit., p. 1-4. 
nonistas franceses que afirmam que a actio nullitatis do direito romano-canônico tornara-se de uso comum para combater os errores in procedendo da sentença, ao final do Século XIII, quando passou a confundir-se com $\mathrm{o}$ recurso de apelação ${ }^{28}$.

Desse modo, diante do desacerto da doutrina e tendo em vista que outras fontes consultadas silenciam sobre o assunto, somos levados a admitir que sob o regime das Decretais, pelo menos em sua fase inicial, não havia ainda se plasmado a comistão entre a exceptio nullitatis das Decretais e a actio nullitatis do processo comum, proclamada pela primeira corrente doutrinária referida. Assim, não se tendo notícia da prática da querella millitatis no regime das Decretais, resta supor-se que tanto as sentenças injustas quanto as nulas por errores in procedendo continuavam a ser impugnadas pelo recurso de apelação, pelo menos nos primeiros tempos de vigência decretais gregorianas.

Para Surgik, no entanto, a sentença nula no regime processual das Decretais estava sujeita ao recurso de cassação, posição que se coaduna com a doutrina que assimila um pelo outro instituto ${ }^{29}$.
A sentença definitiva injusta estava sujeita ao recurso de apelação, para o juiz imediatamente superior ao que proferira a decisão. A apelação é, na atualidade, o único recurso ordinário no sistema canônico.

Devido ao fato do procedimento do sistema canônico dividir-se tradicionalmente em períodos estanques, denominados termini ou stadia, cada uma dessas fases devia encerrar-se com uma sentença interlocutória, que definia também o resultado da prova. As Decretais do Papa Gregório IX, seguindo a tradição do Direito Canônico de admitir a recorribilidade das decisões incidentes, confirmaram a apelabilidade das sentenças interlocutórias, entendendo José Rogério Tucci que estas eram passíveis também da supplicatio, atendidos os pressupostos desse recurso extraordinário ${ }^{30}$.

A sentença definitiva atingia a autoridade de coisa julgada, após alcançar três sentenças conformes, fenômeno que a doutrina canônica chamou tríplice sentença conforme.

A sentença definitiva válida, transitada em julgado, se por algum motivo devesse ser rescindida, poderia sê-lo pelo extraordinário da restitutio

28 NAZ, P. Torquebiau, Raoul; CLERCQ, C. de. Traité de Droit Canonique. Tomo. IV, Des Procès, n. 597. Paris: Letouzey et Ané, Éditeurs, 1954, p. 355-356.

29 SURGIK, Aloisio. Compêndio de Direito Processual Canônico. Cit. p. 34, 380. TUCCI, José Rogério Cruz e. Jurisdição e Poder. cit . p. 125.

30 TUCCI, José Rogério Cruz e. Jurisdição e Poder. cit. p. 125 e edição Saraiva, p. 135, 1987. 
in integrum, satisfeitos os pressupostos necessários.

As Decretais de Gregório IX estabeleceram as bases para a uniformização e a harmonia das Leis da Igreja que se seguiriam, sendo utilizadas nos tribunais e estudadas como livro-texto nas escolas de teologia ao lado do Decreto de Graciano.

Promulgadas como compilação definitiva, proibindo a organização de qualquer outra, salvo o Decreto de Graciano, assim se mantiveram por período de aproximadamente sessenta anos. Mas no pontificado de Bonifácio VIII, este nomeou uma comissão formada por Guglielmo Mandagot, Berengario Predoli e Riccardo Petroni para reunir as leis que tivessem aparecido nesse período, empregando-se o mesmo método de Gregório IX. No início de 1298, o trabalho estava terminado, e pela Bula Sacrosanctae Romanae Ecclesiae, de 3 de março de 1298, Bonifácio VIII promulgou a nova compilação, com a denominação de Livro Sexto, mas que na realidade era dividido em cinco Livros, sendo declarada autêntica, universal e exclusiva, porque ab-rogava todas as outras anteriores às Decretais de 1234 , se nela não se contivessem ${ }^{31}$.

Depois de algum tempo de vigência das Decretais de Gregório IX e do Livro Sexto de Bonifácio VIII, devido à prática do processo escrito que já vinha desde Inocêncio III, em 1210, e ao fato do processo desenvolver-se em fases estanques que se encerravam por um provimento judicial, normalmente uma sententia interlocutoria, tendo de esperar a preclusão do anterior para iniciar-se o seguinte, fez com que o processo se tornasse excessivamente moroso e prejudicial para as partes.

Visando reparar esse mal, o Papa Clemente V (1305-1314) expediu, para uns em 1306, para outros em 21 de março de 1314, a Bula Clementina Saepe Contingit, instituindo o processo sumário, sob a recomendação de que o procedimento devia desenvolver-se simpliciter, breviter, de plano ac sine strepitu ac figura iudicii. Era, assim, instituído um processo rápido, oral e concentrado em uma só oportunidade ou audiência, em contraste com o processo ordinário e escrito.

Esse processo sumário, apesar de concentrado e despojado dos formalismos e dos termini ou stadia estanques do processo ordinário, não trazia limitações nem à produção de provas, nem à defesa do demandado.

A Clementina Saepe Contingit, também conhecida por Constitutiones Clementinae, foi novamente publicada pela Bula Quoniam nulla de 25 de outubro de 1317, de João XXII ${ }^{32}$.

31 GIGANTE, José Antonio Martins. Ob. Cit. V. I, n. 24, p. 29.

32 Acerca do processo nas Decretais de Gregório IX, ver, por todos, SURGIK, Aloísio. Compêndio..., cit ., p. 29-36. 
Com as Clementinas praticamente encerraram-se as compilações da Igreja, e a própria atividade papal se desativou com a transferência da sede Pontifícia para o Avinhão, até o ano de 1377.

\section{Do Cordex Iuris Canonici de 1917}

Como referido anteriormente, sob o ponto de vista material e temporal, compõe a Igreja uma sociedade de homens, unidos não pelos dados puros e simples da sociologia, mas pelos liames naturais da fé e da participação na vida de seu Criador. Nessa perspectiva, tem sido a Igreja concebida por uma ótica tridimensional, como povo, comunidade e sociedade.

Com esta última característica, teve a Igreja necessidade de instituir uma estrutura jurídica própria, que a sedimentou ao curso de sua multimilenar história, embora contestada por alguns episódios transitórios ou duradouros, como o gnosticismo antigo, o espiritualismo medieval, o luteranismo e outros, quase todos amparados no argumento da rejeição do Direito como elemento impuro a uma visão do cristianismo, essencialmente espiritual e radicalmente carismática.
E ao estruturar-se juridicamente, a Igreja o fez fundando um direito próprio - o Direito Canônico -, que embora tenha abeberado em parte esse complexo normativo em fontes e princípios gerais do direito profano antigo, diga-se, não canônico, fixou como núcleo fundamental do seu próprio direito os conteúdos de direito divino, no qual se podem distinguir um direito divino natural e um direito divino positivo, concebidos, o primeiro, como emanação da pessoa humana como ser portador do complexo razão-espírito, e o segundo, como projeção do conceito de Justiça criado por Cristo ${ }^{33}$.

No âmbito dessa complexa estrutura espiritual e temporal, são praticados pela Igreja atos jurídicos de toda ordem, tanto pela imensa comunidade de fiéis como pelas autoridades eclesiásticas, recebendo todos a regência da ordem jurídica canônica, situem-se eles no campo do direito material ou do processo. Há autores, porém, que sustentam não gozarem os atos jurídicos eclesiásticos de disciplina normativa senão na área do processo ${ }^{34}$.

Diante de tais realidades, a Igreja Católica do Ocidente, desde a sua fundação por Cristo, ao início do Principado romano, procurou estabelecer

33 LOMBARDIA, Pedro. Lezioni di Diritto Canônico. Milão: Ed. Giuffrè, 1984, p. 4-15. 34 FALCO, Mario. Introduzione allo Studio Del "Codex Iuris Canonici”. Turim: Ed. Fratelli Bocca Editori, 1925, p. 147. 
sua conduta normativa. No primeiro milênio e até a obra de Graciano, as fontes do Direito Canônico constituíam-se em Encíclicas e Bulas papais, ordens dos concílios e em coleções privadas. Mas com Graciano, e a partir deste, a disciplina normativa eclesiástica toma o caminho da sistematização das suas compilações, já com a intervenção direta e oficial do Romano Pontífice, na elaboração e promulgação de suas leis, com uma visão político-religiosa dos seus próprios destinos. Assim chegou-se à unificação do direito eclesiástico com o primeiro Codex Iuris Canonici, de 1917, após quinze séculos de militância terrena, partindo daí para o amadurecimento da ideia de uma codificação unitária e universal, já concebida no Concílio de Trento (1545-1563) e nos Concílios posteriores, realizado por uma comissão de varões doutíssimos, sob a presidência do canonista Pietro Gasparri.

Com a colaboração conjunta de todo episcopado do universo, o trabalho de codificação estendeu-se por dez anos, estando já quase completo em 1914, quando faleceu Pio X. O Papa Bento XV, seu sucessor, concluiu a obra, anunciando-a ao mundo, pelo Consistorium de 4 de dezembro de 1916, que estava ultimada a codificação, promulgando-a no dia de Pentecostes, pela constituição Providen- tíssima Mater Ecclesia, de 27 de maio de 1917, com vacatio legis de um ano, tendo entrado em vigor na mesma festa de Pentecostes no ano seguinte, ou seja, em 19 de maio de $1918^{35}$.

O Codex Iuris Canonici de 1917 era uma coleção sistemática, unificada, universal e autêntica, redigida não mais pelo método das antigas compilações, mas pela forma das codificações modernas, destinada a reger os destinos de toda a Igreja do Ocidente.

Foram na codificação definidos os Tribunais eclesiásticos, sua estrutura, grau hierárquico e competência, tendo como ato relevante de sua promulgação a substituição da multissecular episcopalis audientia pelo Tribunal Ordinário de primeira instância (cânones 1.572-1.593), estabelecendo-se os órgãos de segunda instância (cânones 1.594-1.596), a Rota Romana e o Supremo Tribunal da Assinatura Apostólica, como instâncias ordinárias e especiais, às vezes extraordinárias. Como Juiz supremo, situado no vértice da pirâmide hierárquica, estava o Romano Pontífice (cânones 1.597-1.605).

$\mathrm{O}$ processo, em sua estrutura funcional, seguia o sistema do direito comum ou romano-canônico esboçado ao final da Alta Idade Média, a partir do Studium civile, de Bolonha, dominado pela escritura (cânon 1.706), 
imprimindo-se no procedimento certo rigorismo formal, inquisitoriedade na produção da prova, observados os princípios do segredo e o inquisitivo, porquanto desde os evangelhos dos primeiros tempos da cristandade, o cristão, para assistir a missa dominical, teria que, antes de tudo, conciliar-se com o irmão desafeto. Vê-se aí um exemplo concreto da prática inquisitória. Por outro lado, o princípio da conciliação continuava a ser considerado princípio transcendental.

Estava o processo dividido em ordinário, especial e administrativo, sendo observado neste último um tipo de procedimento sumário pertinente à remoção de párocos (cânones 2.162-2.167). O processo ordinário era utilizado para as causas em geral; os especiais, diziam com as causas matrimoniais; os administrativos, também chamados processos governativos, diziam com as causas sobre a beatificação de servos e de santificação de beatos, de competência exclusiva da Sé Apostólica (cânones 1.9992.141), bem como abrangiam ainda as causas sobre remoção de párocos inamovíveis e movíveis (cânones 2.1472.167). Também administrativos eram os processos disciplinares contra clérigos irresidentes e concubinários (cânones 2.168-2.181). Aos analfabetos era-lhes deferido o processo oral, devendo a pretensão do autor ser registrada na ata do ofício pelo notário (cânon 1.707).
As sentenças dividiam-se em definitivas e interlocutórias. A outra categoria de ato judicial eram os decretos, definidos por critério de exclusão, isto é, decreto era o provimento judicial destinado a resolver questões incidentes que não pudessem ser resolvidas nem por sentença definitiva, nem por interlocutória (cânon 1.868, § 2º).

As sentenças definitivas, às quais era necessariamente atribuído como requisito essencial a certeza moral, eram os provimentos judiciais que resolviam as questões principais; as sentenças interlocutórias eram as provisões do juiz que dirimiam as questões incidentes.

A sentença definitiva era apelável, quando injusta, (cânon 1.879), mas quando viciada por errores in procedendo, estava sujeita a ser impugnada pela querella nullitatis, expressamente admitida pela codificação de 1.917 (cânones 1.892-1.897), espancando-se, a partir de então, a dúvida que vinha desde as Decretais de Gregório IX, de 1234.

A sentença definitiva que prejudicasse interesse de terceiro podia ser impugnada pelo recurso extraordinário da oposição de terceiro (cânones 1.898-1.901).

O trânsito em julgado da sentença operava-se ocorrida a duplex sententia conformis, reduzindo-se a exigência da triplex sententia conformis do direito anterior (cânon 1.902). A sentença válida, transitada em julgado, 
estaria sujeita à rescisão por meio da restitutio in integrum, se presentes estivessem os pressupostos exigidos para esse recurso extraordinário (cânones 1.902-1.907), isto é, quando a sentença causasse grave dano a um dos litigantes e estivesse manifesta $a$ sua injustiça ${ }^{36}$.

Quanto às sentenças interlocutórias, desde o Concílio de Trento (1545-1563), encontravam-se classificadas em interlocutoriae simplices e em interlocutoriae vim definitivam habentes. As primeiras restaram inapeláveis por decisão do dito Concílio, cujos cânones foram aprovados pela Bula Benedictus Deus, de 25 de janeiro de 1564, do Papa Pio IV. As sentenças interlocutórias com força de definitivas, também chamadas sentenças interlocutórias mistas, assim consideradas as terminativas do processo e as que produzissem dano irreparável ou de difícil reparação ao vencido, se executadas antes da sentença definitiva ou do julgamento da apelação que desta resultasse, continuaram sujeitas ao recurso de apelação (cânon 1.880 § $6^{\circ}$ ). Também era apelável o "decreto" que se revestisse das mesmas características das sentenças interlocutórias com força de definitivas (cânon 1.880, § $6^{\circ}$ ).

\section{Do Codex Iuris Canonici de 1983}

Desde sua fundação por Cristo, mediante atos constitutivos perante os Apóstolos, vinha a Igreja criando e renovando as leis e as demais disposições canônicas, sempre com a finalidade não só de estatuir instrumentos adequados de autorregulamentação de suas atividades no cumprimento da missão salvadora do povo cristão, como também para atender à necessidade de criar e desenvolver um complexo normativo capaz de reger as atividades cristãs dos seus próprios fiéis. O Código de 1983 é a segunda codificação canônica Oficial da Igreja do Ocidente, ainda em vigor até hoje.

Sensível a esses desígnios reformatórios que sempre estiveram presentes no corpo da Igreja, vinha o episcopado de todo o Mundo advertindo ao Romano Pontífice da necessidade de promover-se nova reforma no ordenamento canônico, pois o estatuto vigente, devido à sua vinculação estreita ao sistema de direito comum emergente da Escola de Bolonha e de suas disposições mais voltadas para a disciplina exegético-normativa do que propriamente para os conteúdos de direito divino e de direito apostóli-

36 Sobre a restitutio in integrum na codificação canônica de 1917, ver DOMINGUEZ, Lorenzo Miguélez; MORÁN, Sabino Alonso; ANTA, Marcelino Cabreros de; ORTIZ, José Lopez. Código de Derecho Canônico Comentado. Madri: Ed. BAC, 1976, p. 725. 
co, trazia algumas dificuldades ao desempenho dos papéis da Igreja, diante das novas circunstâncias históricas que se abriam à humanidade após o término da Segunda Guerra Mundial em 1945.

Assim, em 25 de janeiro de 1959, o Papa João XXIII reabriu o Concílio Vaticano I, que anteriormente havia sido suspenso em razão das belicosidades da guerra Franco-Prussiana, e o fez sob a denominação do Concílio Vaticano II, com participação superior a dois mil bispos de todo mundo, no decurso do qual foram promulgadas quatro Constituições: a Lumem Gentium, sobre a Igreja; a Dei Verbum, sobre a revelação; a Sacrossanto Concilium, sobre a liturgia; e a Gaudium et Spes, dispondo sobre as relações da Igreja com o mundo contemporâneo.

Durante as sessões do Concílio Vaticano II, chegaram alguns bispos a esboçar reações antijuridicistas, contrapondo o espírito deste Concílio com o espírito do Código Canônico de 1917.

Todavia, grande parte das conclusões conciliares representavam um avanço fundamental na evolução histórica do Direito Canônico, positivando-se no Concílio princípios de direito divino e, a partir deles, foram delineados outros de direito humano, concernentes à dignidade e à liberda- de do Cristianismo como condição de Povo de Deus; à sacramentalidade e à colegialidade do episcopado; e ainda, ao relacionamento Igreja-Estado, que sugestionaram e deram impulso decisivo à nova reforma do Direito Canônico $^{37}$, atendendo o espírito das quatro constituições suprarreferidas.

Assim, com a revigoração do Concílio Vaticano I, naquele passo designado Concílio Vaticano II, João XXIII, a 28.3.1963, criava a Comissão encarregada de fazer a revisão do Codex de 1917, sob a presidência do Cardeal Pietro Ciarici e sob o secretariado de Jacobo Violardo. Falecido João XXIII, seu sucessor Paulo VI, mediante a Constituição de 17.4.1964, integrou à Comissão novos cardeais, setenta consultores e convocou os canonistas de todo o orbe para que se dedicassem à tarefa da nova codificação.

Falecido o Cardeal Pietro Ciarici, foi em 21.2.1967 nomeado presidente o Arcebispo Péricles Felici, que morreu prematuramente e foi substituído na presidência da Comissão pelo Bispo de Bizacena, da Venezuela, pelo ato pontifício de 17.5.1982.

Decorridos quase quinze anos de trabalhos de revisão, e então já ultimada e impressa, a nova codificação foi entregue ao Sumo Pontífice, em 29.6.1980, na Festa dos Apóstolos Pe-

37 LOMBARDIA, Pedro. Lezioni di Diritto Canônico. Milão: Ed. Giuffrè, 1985, p. 31-40. 
dro e Paulo. Feitas as revisões necessárias, foi o texto novamente editado em 22.4.1982, e o novo Codex Iuris Canonici promulgado por João Paulo II, pela Constituição Apostólica Sacrae Disciplinae Leges, de 25.1.1983, na mesma data em que vinte e quatro anos antes João XXIII havia lançado a ideia ao criar o Concílio Ecumênico Vaticano $I^{38}$. O novo Código entrou em vigor no primeiro dia do Advento, ou seja, em 27.11.1983, como determinara a dita Constituição Apostólica que o promulgou.

O Codex Iuris Canonici de 1983, que se compõe de 1.752 cânones, é mais sintético e concentrado que o Codex anterior de 1917, que era composto por 2.414 cânones. Encontra-se dividido em sete Livros, disciplinando em cada um deles todas as funções, encargos, direitos e deveres da Igreja, dos clérigos e do tratamento do Povo de Deus, a respeito do qual se destacam as funções de ensinar e santificar.

No que se refere à jurisdição eclesiástica, o Código cuida especialmente da organização dos tribunais. São esses os órgãos da jurisdição da Igreja encarregados dos misteres do processo canônico. Na linguagem da canonística, o vocábulo “tribunal” não tem a mesma significação da linguagem do direito secular, onde a expressão sempre identifica um órgão colegiado. No processo canônico, o tribunal pode ser composto por iudex unicus ou por um collegium, segundo as circunstâncias, sendo esse colégio formado por clérigos e outros membros, como o relator, o auditor, o assessor, o promotor, o defensor do vínculo, o notário e o oficial de justiça, embora nem todos tenham o múnus de julgar.

Juiz nato em cada diocese é o Bispo, o qual, além da potestade estritamente judicial, tem também a função governativa sobre os tribunais e, em razão disso, dirige o processo, nomeia o relator e os demais auxiliares, fiscaliza e disciplina as atividades do tribunal $^{39}$.

Na primeira instância, está o Tribunal Diocesano (cânones 1.4191.426), que no estatuto anterior denominava-se Tribunal Ordinário de primeira instância (cânones 1.5721.593) e que naquele passo havia substituído a ultramilenar episcopalis

38 ECHEVERRÍA, Lamberto de et al. Código de Derecho Canônico (de 1983). Ed bilíngue comentada. "Prefácio”. Madrid: Biblioteca de Autores Cristianos, 1985, p. XXXIX a LII.

39 ANTA, Marcelino Cabreros de. Código de Derecho Canônico (de 1917). Ed. bilíngue latim-espanhol (comentada). Madrid: Biblioteca de Autores Cristianos, (BAC), 1974, p. 610-611. 
audientia que vinha desde o início da cristandade, figurando como tribunal de primeiro grau. Pode haver um tribunal diocesano para abranger mais de uma diocese (cânon 1.423).

Na segunda instância, situam-se o Tribunal Metropolitano, também chamado Tribunal do Arcebispo (cânones 1.438-1.441), podendo ser designado outro para julgar a apelação, quando o metropolitano tiver decidido a causa como instância originária (cânon 1.438, $\S 2^{\circ}$ ). O tribunal de segunda instância para julgamento do recurso é sempre colegiado (cânon 1.441).

Na terceira instância estão os Tribunais da Sé Apostólica, constituída pela Rota Romana e pelo Supremo Tribunal da Assinatura Apostólica (cânones 1.442-1.445). A Rota Romana muitas vezes se constitui em tribunal ordinário de segunda instância (cânones 1.443-1.444), ou até como tribunal de primeira instância nas causas criminais contra os bispos, bem como as que o Romano Pontífice, tanto motu próprio como a instância de parte, tenha avocado ao seu tribunal e a tenha encaminhado à Rota Romana para julgamento inicial (cânon 1.444, § $2^{\circ}$ ).

O Supremo Tribunal da Assinatura Apostólica é sempre instância extraordinária. O Romano Pontífice é o juiz supremo para todo o orbe católico pertencente à Igreja do Ocidente ou Igreja Latina (cânones 1.404 e 1.442).

O processo, no Codex Iuris Canonici de 1983, divide-se em contencioso ordinário, em contencioso oral, em especiais, em administrativo e em penal. O contencioso ordinário é o residual, utilizado para todas as causas em geral, a cujo procedimento a lei não atribua um outro rito (oral, especial, administrativo, penal); os processos especiais são aqueles ritualizados de maneira diversa ao contencioso ordinário, em que o procedimento apresenta peculiaridades distintas das comuns a todos os casos (cânones 1.671-1.716), como soe acontecer com as causas matrimoniais, em que há a interveniência de um defensor do vínculo e não sujeição à coisa julgada etc. (cânones 1.432 e 1.643).

Processos administrativos são os de declaração de nulidade de ordenação de clérigos (cânones 1.708=1.716), os de remoção e traslado de párocos (cânones 1.740-1.752) e outros menos frequentes. Os processos penais são processos mistos, nos quais há uma fase investigatória extrajudicial, chamada investigação prévia ou de natureza administrativa ${ }^{40}$ a qual, se não chegar a indicar a persecução penal contenciosa, será arquivada nos arquivos secretos da Cúria (cânones

40 ACEBAL, Juan Luis. Código de Derecho Canônico (de 1983). Ed. bilíngue latimespanhol. Madrid: Biblioteca de Autores cristianos (BAC), 1985, p. 828-834. 
1.717-1.739). A fase contenciosa penal só será promovida se a investigação prévia concluir que há elementos para tal (cânones 1.720-1.731).

O Processo contencioso oral assume as características do processo sumário criado pela Bula Clementina Saepe Contingit de 21 de março de 1314, de Clemente V. Porém, o processo sumário puro, instituído na dita Bula Clementina, não foi expressamente adotado pelo Codex de 1983. O procedimento no contencioso oral deve concentrar-se em uma só audiência, na qual deve esgotar-se toda a atividade processual, à semelhança do que ocorria com o processo austríaco do Código de Franz Klein de 1895 e com o atual Código General Del Proceso do Uruguai, editado em 18.10.1988 e em vigor a partir de 20.11.1989, que adotou o chamado proceso por audiências (arts. 340-342), cuja audiência preliminar concentra praticamente toda a matéria de cognição. Dentre as causas excluídas do processo contencioso oral, no Codex de 1983 estão as de nulidade de matrimônio ${ }^{41}$.

No que se refere ao procedimento, o novo Codex Iuris Canonici ainda mantém-se atrelado ao sistema do processo comum, que resultou na Alta Idade Média da comistão que se operou da convivência do processo canônico com o romano e em contato com o processo germânico primitivo. Assim, embora a nova codificação tenha buscado caminhos em direção ao processo científico moderno, o procedimento ainda se pauta por certo rigorismo formal, identificado com o processo romano-canônico que dominou o processo secular ou profano até meados do século XVIII.

O princípio da escritura, que vinha desde Inocêncio III, na Bula Quoniam Contra de 1210, anteriormente às Decretais gregorianas, sob o fundamento de que os atos processuais devem se perpetuar nos autos (quod non est in actis, non est in mundo), foi mantido, de tal modo que, mesmo no contencioso oral, os atos devem ser reduzidos a escrito pelo notário, sob pena de nulidade (cânon 1.437).

Não obstante serem os atos do processo praticados com obediência ao princípio dispositivo (cânon 1.501), há casos em que prevalece o princípio inquisitivo, quando na demanda se desenhar o interesse da Igreja ou o da salvação das almas (cânon 1.453). É mantido o princípio do segredo dos atos judiciais por juízes, testemunhas, peritos, partes e seus advogados e auxiliares do juízo até a sentença. $\mathrm{O}$ princípio da publicidade é, pois, exceção no processo canônico ${ }^{42}$.

41 HORTAL, Pe. Jesus. Código de Direito Canônico. (Comentado), trad. Portuguesa. São Paulo: Ed. Loyola, 1987, p. 710-711.

42 HORTAL, Pe. Jesus. Código de Direito Canônico. (Comentado), trad. Portuguesa. São Paulo: Ed. Loyola, 1987, p. 640. 
Encerradas as fases postulatória e instrutória, segue-se, obviamente, a fase decisória cujos atos se incluem no gênero "Dos Pronunciamentos do Juiz", entre os quais figuram as sentenças e os decretos. As sentenças dividem-se em definitivas e interlocutórias, confundindo-se estas últimas algumas vezes com os decretos.

A sentença definitiva é a decisão judicial por excelência, pois inegável é a sua função como ato de declaração do direito em concreto e como meio de satisfação do direito divino natural ou positivo reclamado pela pessoa do fiel ou do clérigo. E essa função transcende amplamente a ideia de aplicação pura e simples da norma positiva, pois, no caso de inexistência desta, deverá o juiz, a teor do cânon 19, recorrer: aos princípios gerais de direito, aplicados com equidade canônica; à jurisprudência e às práticas da Cúria Romana; e à opinião comum e constante dos doutores, salvo em causas penais. É, pois, a sentença definitiva, o ato culminante do processo, no qual o juiz exerce a plenitude da potestade jurisdicional de que está investido e responde adequadamente ao direito de ação e de defesa mediante a resolução da controvérsia. É o fim a que se destina o processo e a luz que ilumina as trevas da controvérsia.
A inabalável convicção acerca da verdade insculpida no complexo probatório lhe ensejará a certeza moral, um dos requisitos internos indispensáveis da sentença canônica (cânon 1.608). É a certeza - afirma a doutrina canônica - que exclui toda a dúvida fundada ou imaginável acerca dos fatos da causa, que elimina a probabilidade da incerteza, ainda que não a possibilidade desta vir a ocorrer. Diz-se, pois, que a certeza moral exclui a probabilidade de errar, mas não a possibilidade. Considera que o erro é improvável, ainda que possível ${ }^{43}$. Outro requisito interno da sentença canônica é da motivação, que no Codex de 1983 constitui exigência legal expressa (cânon 1.611, § $3^{\circ}$ ).

A sentença nula, ou viciada por errores in procedendo, está sujeita ao recurso extraordinário da quarella nullitatis (cânones 1.619-1.627), no prazo de dez dias, como ação e, perpetuamente, como exceção (cânon 1.621). A sentença válida, porém injusta, que padece de errores in iudicando, está sujeita ao recurso de apelação, que se realiza em duas etapas: a primeira, no prazo de quinze dias úteis, estipulado para o apelante fazer o pedido perante o juiz a quo (cânon 1.630); a segunda, dentro de um mês, quando o recorrente deve formular as

43 É o pensamento de ACEBAL, Juan Luis. Código de Derecho Canônico (de 1983). Ed. bilíngue latim-espanhol. Madrid: Biblioteca de Autores cristianos (BAC), 1985, p. 783. 
razões do recurso perante o tribunal ad quem (cânon 1.633).

A sentença transita em julgado após a ocorrência de duas sentenças conformes (duplex sententiae conformes) (cânon 1.641, § $1^{\circ}$ ).

A sentença válida, transitada em julgado, estará sujeita a ser rescindida por meio do recurso extraordinário da restitutio in integrum, se estiverem presentes os requisitos para o cabimento desse meio recursal exigidos (cânon 1.645-1.648). Entre os requisitos fundamentais para embasar o recurso estão a iminência de grave dano a um dos litigantes e a manifesta injustiça da sentença, como é o caso da sentença obtida com dolo de uma parte que venha acarretar prejuízo à outra ${ }^{44}$.

As sentenças interlocutórias, ou seja, aquelas que decidem questão incidente ou que decidam uma questão processual terminativa do processo, são muito comuns no processo canônico, devido às características deste, de ter o seu procedimento dividido em termini ou stadia estanques, cada um deles encerrado por uma sentença interlocutória ou por um decretum. Esse fator, ligado à preclusão herdada do processo germânico, ocorrida no encerramento de cada uma dessas fases, torna recorríveis as decisões que as resolvem.
Esses fatos, que vinham ensejando uma ampla recorribilidade no processo canônico, com sérios prejuízos para o bom andamento do processo, fez com que as autoridades eclesiásticas reunidas no Concílio de Trento (1545-1563) optassem por classificar as interlocutórias em sententiae interlocutoriae vim definitivam habentes e em sententiae interlocutoriae símplices, subdividindo as primeiras em interlocutórias terminativas do processo e em interlocutórias que causam irreparável prejuízo ou de difícil reparação ao vencido. Como até então todas as sentenças interlocutórias eram apeláveis indistintamente, os conciliares tridentinos limitaram o recurso de apelação às primeiras, isto é, às sentenças interlocutórias com força de definitivas, proscrevendo-o para as interlocutórias simples, que, em consequência, restam revogáveis pelo juiz a qualquer tempo, até a sentença definitiva final, eis que sobre elas não mais recai preclusão, conforme os cânones do mencionado Concílio, aprovados pelo papa Paulo IV, na Bula Benedictus Deus de 25 de janeiro de 1564.

Essa situação já havia sido recolhida pelo Codex de 1917 (cânones 1.841 e 1.880 , $\S 6^{\circ}$ ), sendo conservada pela codificação atual de 1983 (cânones 1.591 e 1.629 , § $4^{\circ}$ ).

Desse modo, na vigência do presente Codex Iuris Canonici de 1983,

44 ACEBAL, Juan Luis. Código de Derecho Canônico (de 1983). Ed. bilíngue latimespanhol. Madrid: Biblioteca de Autores cristianos (BAC), 1985, p. 799-800. 
são atacáveis pelo recurso de apelação, além das sentenças definitivas, as sententiae interlocutoriae vim definitivam habentes, segundo as normas do cânon 1.639, § $4^{\circ}$ da dita codificação, restando inapeláveis e por isso revogáveis pelo juiz a qualquer tempo, até a prolação da sentença definitiva final, as sentenças interlocutórias simples, de que se ocupa o cânon 1.591 da codificação vigente.

Situação paralela à das sentenças interlocutórias é a do decretum, que, na sistemática do Codex, é o provimento judicial próprio para decidir e encerrar as fases introdutória, probatória e de discussão do processo de conhecimento de primeira instância. Segundo os mesmos dispositivos legais acima referidos (cânones 1.591 e 1.639, § $4^{\circ}$ ), é apelável o decreto com força de sentença definitiva (cânon 1.639, § $4^{\circ}$ ), restando irrecorrível e revogável o decreto que não tenha força de definitiva (cânon 1.591), o que faz supor que só não é recorrível o decreto de expediente ou de mero expediente, para usar-se uma linguagem tradicional do processo secular moderno.

Na vigência do Codex de 1983, restam inapeláveis os seguintes provimentos judiciais (cânon 1.629): as sentenças do Pontífice Romano ou do Supremo Tribunal da Assinatura
Apostólica; a sentença viciada de nulidade, salvo quando for a apelação cumulada com a querela de nulidade (cânon 1.629, § $2^{\circ}$ ); a sentença transitada em julgado; o decreto do juiz ou sentença interlocutória que não tenha força de definitiva, salvo se cumulada com a apelação da sentença definitiva; a sentença ou decreto em causa em que a lei determina sejam dirimidas com a maior rapidez (cânon 1.629), $\S 5^{\circ}$ ).

Por fim, é de notar que todas as disposições canônicas até aqui referidas dizem respeito ao Direito Canônico da Igreja Ocidental, pois o Direito Canônico Oriental até o presente nunca chegou a ser codificado, embora haja um andamento processo de reforma ${ }^{45}$.

\section{Contribuições da canonística no âmbito do direito público estatal e quanto aos princípios gerais de direito}

Quanto ao exercício do poder, divide-o no seu âmbito a canonística em poder legislativo, em poder executivo e poder judiciário, estabelecendo a constituição e composição de cada um (cânon 1.350 e os modos de atuação de cada poder). O primeiro, constituído pelos prelados da Igreja (cânon 135, 2º); o segundo, formado pelos prelados e delegados consagra-

45 HORTAL, Pe. Jesus. Código de Direito Canônico. (Comentado), trad. Portuguesa. São Paulo: Ed. Loyola, 1987, p. 2. 
dos ou eleitos; o terceiro, exercido por juízes e colégios judiciais instituídos pelas leis canônicas (cânones 135 a 145). Aí está a divisão de poderes pertinentes ao governo da Igreja estabelecida pela canonística, do mesmo modo como faz a Lei Maior do Estado Democrático de Direito na atualidade, o que demonstra a próxima semelhança entre o Direito da Igreja e o estatal público e, quem sabe, a contribuição daquele para a formação deste.

Contribuições da canonística à ordem jurídica estatal existem também quanto a certos princípios gerais de direito. Assim ocorre, exemplificativamente, com a observância pela canonística dos direitos adquiridos (cânon 4); com a observância dos costumes em situações não previstas na lei canônica (cânon 5); com a adoção do princípio da irretroatividade da lei nova às situações fáticas ocorridas no passado (cânon 9); com o princípio que veda a aplicação de restrições de direitos a casos não expressamente previstos na lei canônica (cânon 18); com o princípio que recomenda a aplicação da equidade com espírito de benignidade entre os princípios gerais de direito (cânon 19); com o princípio de que a lei posterior ab-roga ou derroca a anterior, se expressamente o declara, se lhe é diretamente contrária ou se reordena inteiramente toda a matéria da lei anterior (cânon 20); e muitas outras situações dispostas na lei canônica que, de igual modo, são contempladas nas leis estatais, também chamadas leis seculares.

\section{Contribuições da canonística na área do processo}

No que diz respeito ao âmbito do processo, vinha a canonística, desde os mais remotos tempos, mais ordenadamente a partir do Decreto de Graciano, no ano de 1140 d.C., pugnando por uma estrutura orgânica do processo canônico, para colocá-lo em prática com o objetivo de atender os desígnios da Igreja do Ocidente. A missão dos organizadores do Decretum foi a de proclamar as figuras do juiz imparcial (verus iudex); qualificar o magistrado pelos critérios morais (bonus iudex); estabelecer a pluralidade de graus de jurisdição; instituir como princípios fundamentais a triplex sententia conformis e a certeza moral, para a formação da "res iudicata"; a repristinação da "episcopalis audientia" ou tribunal do bispo, que vinha sendo processado desde os primeiros tempos da cristandade; a classificação da sentença em definitiva e interlocutória, sujeitando a primeira ao recurso da "appellatio" e a segunda ao recurso "per saltum", para a Sé Apostólica, em certos casos.

É de notar, pois, que a proclamação do "verus iudex" e do "iudex bonus" assemelham-se aos institutos do impedimento e da suspeição, no 
processo estatal, respectivamente, enquanto o princípio da "triplex sententia conformis" implica similitude com o do trânsito em julgado da sentença, na atualidade, em face do esgotamento das vias recursais.

No estágio das Decretais de Gregório IX, de 1234 d.C., seguintes ao Decreto de Graciano, de 1140, foi instituída e definida "in ius vocatio", para chamar o réu ao processo e assim exercitar a sua defesa consubstanciada na "contestatio" e em todas as demais "exceptiones", para formar a "res in indicio deducta" a ser decidida pelo "arbiter". Ainda no período de vigência das Decretais, surgiu a "Clementina Saepe Contingit" do Papa Clemente V (1305-1314), instituindo o procedimento sumário que deveria se desenvolver "simpliciter, breviter, de plano ac sine strepitu ac figura iudici", para suplantar a morosidade processual decorrente da apelatividade das interlocutórias etc. Esses dois institutos da "in ius vocatio" e do processo sumário, criados no estágio das Decretais do Gregório IX, revelam contribuições importantes para implementar os procedimentos da citação e da ação sumária no processo estatal moderno.

Outras tantas contribuições do processo canônico ao processo estatal moderno vêm sendo espelhadas nas duas codificações canônicas oficiais de 1917 e 1983, como se verá a seguir.

Concebida no Concílio de Trento, realizado entre 1545 e 1563, a ideia de substituir e sistematizar a disciplina normativa eclesiástica, até então sob a égide das compilações esparsas, muitas delas de elaboração particular e privada de alguns canonistas, partiu a Igreja para a unificação de sua visão político-religiosa, mediante a organização de uma codificação que veio a lume com a promulgação do "Codex Iuris Canonici de 1917, levada a público por Bento XV, com a Constituição "Providentissima Mater Ecclesia”, de 25 de maio de 1917, tendo entrado em vigor na mesma data do ano posterior.

Essa codificação, que foi elaborada não mais pelo método das compilações anteriores, mas seguiu a sistematização e a unidade adotadas nas Decretais de Gregório IX e a forma imprimida nas codificações modernas, com seu texto dividido em cinco Livros, teve a singularidade de substituir, na área do processo, a multissecular "episcopalis audientia" pelo Tribunal Ordinário de primeira instância (cânones 1.572-1.593), estabelecendo como órgãos de instância superior, ordinária e especial, os Tribunais da Sé Apostólica, tais como o da Rota Romana e o Supremo Tribunal da Assinatura Apostólica, figurando no ápice da pirâmide hierárquica, como Juiz Supremo, o Romano Pontífice.

Todos os demais institutos e procedimentos pertinentes ao processo canônico e admitidos pela codificação oficial de 1917 estão repristinados no estatuto canônico de 1983, como se verá adiante. 
A promulgação do "Codex Iuris Canonici" de 1983, reformando a codificação oficial anterior, foi sensível aos desígnios reformatórios que estiveram presentes no corpo da Igreja, manifestados pelo episcopado de todo o mundo, desde as primeiras décadas de vigência do "Codex" de 1917, situação que levou o Sumo Pontífice João Paulo II a expedir a Constituição Apostólica "Sacrae Disciplinae Leges”, de 25 de janeiro de 1983, promulgando o novo código, que entrou em vigor no primeiro dia do Advento, em 27 de novembro de 1983, como determinara a dita Constituição Apostólica que o promulgou.

A atual e vigente codificação, ao tratar dos órgãos da jurisdição eclesiástica, encarregados dos misteres do processo canônico, estabeleceu como juízo de primeiro grau o Tribunal Diocesano (cânones 1.419-1.437), tendo como juízo de segundo grau o Tribunal Metropolitano, também chamado Tribunal do Arcebispo (cânones 1.438-1.441). Como órgãos de terceiro grau ou de instância extraordinária, ou especial, os Tribunais da Sé Apostólica, constituídos pela Rota Romana e o Supremo Tribunal da Assinatura Apostólica (cânones 1.442-1.445), salientando-se que o Romano Pontífice é sempre o juiz supremo em todo o orbe católico da Igreja do Ocidente ou Igreja Latina (cânones 1.404-1.442).

O processo, na codificação canônica de 1983, divide-se em contencioso ordinário, contencioso oral, especial, administrativo e penal, constituindo-se procedimento residual o contencioso ordinário, para todas as causas a cujo procedimento a lei não atribuir outro rito, como soe ocorrer com as causas matrimoniais, nas quais deve atuar também o defensor do vínculo (cânon 1.430). O processo sumário puro, criado pela "Clementina Saepe Contingit” de 1314, não foi expressamente adotado pela atual codificação. No entanto, é sabido que o procedimento contencioso oral deve concentrar-se em uma só audiência, como no Código Austríaco de Franz Klein e no atual Código General Del Proceso, do Uruguai (arts. 340-342), em vigor a partir de 20 de novembro de 1989.

Os provimentos judiciais, que se incluem no gênero denominado "Dos Pronunciamentos do Juiz”, (cânon 1.607), estão divididos em sentenças definitivas, sentenças interlocutórias e decretos. A sentença definitiva deve estar exornada da certeza moral sobre a verdade dos fatos, requisito que, segundo a doutrina canônica, oportuniza ao juiz uma sentença justa, qualidade sentencial que o canonismo sempre exigiu no andar dos tempos. A sentença definitiva válida e justa está contingencialmente sujeita ao recurso da "appellatio", e se transitada em julgado após duas sentenças conformes, submetida à "restitutio in integrum”, em determinadas hipóteses. As sentenças interlocutórias, 
classificadas pelo Concílio de Trento (1545 a 1563, em "interlocuoriae vim definitivae habentes", também chamadas mistas, e "interlocutoriae simplices”, sendo apeláveis as primeiras e irrecorríveis as segundas, por serem revogáveis a qualquer tempo, antes da sentença final (cânon 1.629, § $4^{\circ}$ ). Os decretos são provisões judiciais para solução de atos processuais que não tenham a categoria de sentença definitiva (cânon 1.629, §§ $4^{\circ}$ e $5^{\circ}$ ).

Assim, deve-se notar que, também na área do processo estatal, vem a canonística, desde os primeiros tempos, oferecendo continuadas contribuições à formação de institutos e práticas processuais contempladas por esse setor da ordem jurídica em tempos atuais.

\section{Contribuições da canonística à formação dos institutos de direito de família na área do direito estatal}

Além das contribuições da canonística registradas acima, acerca da formação e adoção de regras e práticas a serem observadas em outros ramos da ordem jurídica estatal, é, sem dúvida, na esfera do direito de família que tais contribuições da canonística se revelam com maior intensidade e relevância. É de notar-se que essas contribuições vêm desde épocas anteriores, pois já as Decretais de Gregório IX, de 1234, dedicavam inteiramente o seu Livro IV para tratar dos “connubia”. Isso vem ocorrendo indubitavelmente, porque a constituição da família, que modernamente é considerada base da sociedade na expressão constitucional, tem sua gênese e formação inicial nos primeiros seres humanos habitantes do Mundo, de modo que, desde então, tornou-se necessária a instituição de regras e comportamentos para preservar e disciplinar a vida, as funções, as garantias, direitos e deveres da célula familiar e dos seus componentes e, tal como registra a história, foi nas instituições canônicas que se plasmaram inicialmente os primeiros regramentos dessa entidade humana.

Concreta e materialmente, as primeiras e principais fontes do direito de família consubstanciadas nas regras sobre casamento, impedimentos e causas suspensivas que maculam ou transformam a eficácia do ato nupcional; nas formas comuns e excepcionais da sua deliberação pelos nubentes; a legitimidade ou não da filiação etc. estão na canonística, emanadas desde as primeiras Encíclicas, Bulas e outras manifestações papais e, ainda, em compilações privadas de prelados católicos, que vêm sendo sedimentadas na multissecular atuação da Igreja do Ocidente, para cumprir os seus próprios desígnios, na missão de ensinar, santificar e reger os destinos do seu povo.

Assim, exercendo seu poder normativo, a Igreja do Ocidente define e 
caracteriza o pacto matrimonial (cânon 1.055), ao proclamar sua unidade e indissolubilidade (cânones 1.057 e 1.058), proscrevendo implicitamente a poligamia; estabelece os impedimentos matrimoniais (cânones 1.077 a 1.078); as invalidades do ato conjugal entre parentes na linha reta de consanguinidade, do parentesco afim e na linha transversal (cânones 1.091 e 1.092); a incapacidade para contrair núpcias na falta de idade núbil (cânones 1.095 e 1.096); as formalidades exigidas para a validade desse ato solene (cânones 1.108 a 1.123); a dispensa de formalidades e requisitos para os casamentos in extremis inclusive sob a forma nuncupativa (cânon, 1.068); os efeitos positivos e negativos do matrimônio (cânones 1.134 a 1.140); os deveres recíprocos dos cônjuges entre si e com os filhos (cânones 1.134 a 1.140); a dissolução por anulação do ato conjugal, quando não consumado, por inexistência de sexo entre os cônjuges (cânones 1.141 e 1.142); a separação dos cônjuges com dissolução do vínculo (cânones 1.143 a 1.150) e sem dissolução do vínculo (cânones 1.151 a 1.155); os esponsais (sponsalia de presenti) não obrigam a realização do casamento (cânon
$1.062, \S 1^{\circ}$ e sponsalia de futuro), prescrevendo a reparação civil quando cindido unilateralmente o pré-contrato matrimonial (cânon 1.062, §§ $1^{\circ}$ e $2^{\circ}$ ); e muitos outros casos específicos poderiam ser aqui trazidos à baila.

A par das prescrições canônicas expedidas pelas mais remotas manifestações epistolares da Igreja no andar dos tempos e agora positivadas na própria codificação oficial, a doutrina eclesial vem buscando variadas interpretações sobre situações pertinentes ao direito de família, notadamente quanto às tratadas no Concílio de Trento (1.545-1.563) e mais recentemente na Encíclica casti connubii, de Pio XI. Um dos exemplos dessa interpretação, que se alicerça no âmbito do direito divino, diz respeito ao adultério, segundo a qual o descumprimento desse dever conjugal por um dos nubentes não constitui causa para a dissolução do vínculo para o casamento ratificado e consumado (cânon 1.141), devido à sacralidade desse ato nupcial, salvo a hipótese referida no cânon $1.152^{46}$. Muitas outras posições interpretativas acerca das normas positivadas na codificação canônica oficial vêm sendo tomadas pela doutrina eclesial $^{47}$.

46 HORTAL, Pe. Jesus. Código de Direito Canônico. (Comentado), trad. Portuguesa. São Paulo: Ed. Loyola, 1987 (Codex de 1983). Comentários aos cânones 1.141 e 1.152, Edições Loyola, p. 502, 503, 508 e 509.

47 Para a verificação extensiva dessas manifestações interpretativas, consultar a obra de HORTAL, Pe. Jesus. Código de Direito Canônico. (Comentado), trad. Portuguesa. São Paulo: Ed. Loyola, 1987. 
Constata-se, assim, as mais efetivas contribuições canônicas, com anterioridade multissecular e com enorme prevalência na área do direito de

\section{REFERÊNCIAS}

ABADIA, Jesus Lalinde. Derecho Histórico Español. Barcelona: Edição Ariel, 1974.

ACEBAL, Juan Louis. Código de Derecho Canónico, Ed. Bilíngue comentada (latim-español), Madrid: Biblioteca de Autores Cristianos (BAC), 1985.

ARIAS, José Salazar. Dogmas e Cânones de La Iglesia em el Derecho Romano. Madrid: Instituto Editorial Reus, 1954.

AZNAR, Frederico. Código de Derecho Canónico. Ed. Bilíngue Comentada. Cânon 129. Madrid: Ed. BAC, 1985, p. 104.

CIPROTI, Pio. Lezioni di Diritto Canônico. Padova, Ed. CEDAM, 1943.

CRUZ e TUCCI, José Rogério. Constituição de 1988 e Processo. São Paulo: Ed. Saraiva, 1989. . Jurisdição e Poder. São Paulo: Ed. Saraiva, 1987.

DE ANTA, Marcelino Cabreros. Código de Derecho Canónico Comentado (de 1917). Ed. Bilíngue (Latim-español). Madrid: Ed. BAC, 1976.

DELLA ROCCA, Fernando. Appunti sui gravami nel Processo Canóni- família, porque este é o setor tutelar da ordem jurídica das relações mais próximas íntimas e valorativas da vivência humana.

co. In: Saggi di Diritto Processuale Canónico. Padova: Ed. CEDAM, 1961.

DOMINGUEZ, Lourenzo Miguélez. Código de Derecho Canónico Comentado (de 1917). Madrid: Ed. Biblioteca de Autores Cristianos (BAC), 1976.

ECHEVERRIA, Lamberto de. "Prefácio" del Código de Derecho Canónico Comentado (de 1983). Ed. Bilíngue (Latim-español). Madrid: Ed. Biblioteca de Autores Cristianos (BAC), 1985.

FALCO, Mario. Introduzioni di Diritto Canónico. Milano: Edizione Giufrè, 1984.

GARCIA y GARCIA, Antonio. História Del Derecho Canónico El Primer Milenio. Salamanca, 1967.

GIGANTE, José Antonio Martins. Instituições de Direito Canónico. Braga: Ed. Escola Tipográfica da Of. São Jose, 1951.

GILISSEN, John. Introdução Histórica ao Direito. Lisboa: Ed. Fundação Calouste Gulbenkian, 1986.

GOMES DA SILVA, Nuno Espinosa. História do Direito Português. 
Lisboa: Ed. Fundação Calouste Gulbenkian, 1988.

GUASP, Jaime. Comentários à Ley de Enjuiciamiento Civil (LEC). Tomo I. Madrid: Aquilar Editor, 1948. HERNANDEZ, Miguel Moreno. Derecho Procesal Canónico. Madri: Ed. Aguilar, 1956.

HORTAL, Pe. Jesus. Código de Direito Canónico (Comentário). São Paulo: Edições Loyola, 1987.

LIEBMAN, Enrico Tullio. Appunti Sulle Impugnazioni (ristampa). Milano: Ed. Cisalpino Golliardica,1961.

LOMBARDIA, Pedro. Lezioni di Diritto Canónico. Milano: Ed. Giuffrè, 1984.

MARRYMANN, Johnm Henry. La Tradición Juridica Romano-Canónica. Trad. espanhola de Carlos
Sierra. México: Ponto de Cultura, 1971.

PELLEGRINO, Piero. I Provvedimenti Interlocutori nella Teoria canonistica delle Impugnazioni. Padova: Ed. CEDAM, 1969.

PERTILE, Antonio. Storia Del Diritto Italiano. V. VI (Storia della Procedura). Torino: Unione Tipografica Editrice Torinese, 1990.

SALVIOLI, Giuseppe. Storia Del Diritto Italiano. V. II. Frankfurt: Ed. Sauer Auvermann KG, Libreria, O. Sozzini, Flrenze, 1969.

TORQUEBIEAU, P. Raoul Naz. Traité de Droit Canonique. Paris: Letouzei et Ané, Editeurs, 1954. WIEACKER, Franz. História do Direito Privado Moderno. Lisboa: Ed. Fundação Calouste Gulbenkian, 1967. 